\title{
Separation of CPO Using Megasonic Clarification System and Cooking of Palm Fruitlets Using Ultrasonic Horn Press System
}

\author{
Vetrimurugan ${ }^{1}$, Terry Lim $^{2}$, J. Michael Goodson ${ }^{3}$ \\ Cleaning Development Manager, Crest Ultrasonics, Penang, Malaysia ${ }^{1}$ \\ Executive Vice President (Asia) of Crest Group Inc, Malaysia ${ }^{2}$ \\ CEO, Crest Ultrasonics Corporation, $U_{S A}^{3}$
}

\begin{abstract}
In this study an eco-mill system with new technology was developed to overcome the current palm oil mill issues such as vast Palm Oil Mill Effluent (POME) ponds, large mill area, reliance on water supply, oil quality, oil loss, and energy etc. In eco-mill process two distinct technologies such as megasonic clarification system and ultrasonic horn press system was developed to replace the conventional clarification system and sterilization system. Megasonic clarification process can separate the Crude Palm Oil (CPO) more effectively without any dilution (no additional water required) and within short period of time with lowest temperature $\left(\sim 80{ }^{\circ} \mathrm{C}\right)$. This results in high quality oil with minimum oil loss. Ultrasonic horn press system can rupture the oil cells within the palm fruits and also press the oil emulsion out from the fruits within 20 sec with controlled temperature $\left(\sim 70{ }^{\circ} \mathrm{C}\right)$. These changes can influence POME treatment process and at the same time reduce the treatment cost significantly. The issues of environmental pollution due to POME can be greatly reduced. The frequency ranges studied for CPO clarification process was $40 \mathrm{kHz}-1 \mathrm{MHz}$ and the temperature range studied was $60{ }^{\circ} \mathrm{C}$ to $90{ }^{\circ} \mathrm{C}$. The effect of various watt densities on oil separation was also studied. Result shows that $360 \mathrm{kHz}$ would be the more appropriate frequency to separate the oil from its entrained impurities within short period of time. The result also shows that higher watt density gives faster separation of CPO. Megasonic clarification with $80{ }^{\circ} \mathrm{C}$ gives better oil quality and faster separation as compared to other temperatures tested. Result also indicates that the DOBI value decreases with increase of temperature over $85{ }^{\circ} \mathrm{C}$. The ultrasonic horn press takes only $20 \mathrm{sec}$ to rupture/burst the oil bearing cells in the fruitlets. This indeed reduces the cycle time drastically as compared to conventional sterilization system.
\end{abstract}

Keywords- Palm oil, POME, Megasonic clarification, Ultrasonic horn press, Frequency

\section{Introduction}

Palm oil industry forms the economic backbone of Malaysia because Malaysia is one of the largest exporters of palm oil in the world [1 - 2]. World production of palm oil had increased tremendously during the last 30 years as a result of rapid expansion of oil palm planting mainly in Malaysia and Indonesia [3]. Even though, rapid expansion of palm oil planting but the technology is still remains same except small improvements along the years. There is no major breakthrough in the technology and thus the issues of large mill area, reliance on water supply, the Palm Oil Mill Effluent ponds, carbon dioxide emission and footprint still remains same.

In eco-mill process, state of the art megasonic clarification system and ultrasonic horn press system was developed to overcome the current milling issues by replacing conventional clarification system, sterilization system and some of the other associated process. The main source of environment pollution in the conventional oil mill is the pond system used to store the palm oil mill effluent (POME) which was created during dilution in the clarification tank, screw press etc. Each ton of produced crude palm oil is responsible for the emission of $46 \mathrm{~m}^{3}$ (32.9 $\mathrm{kg})$ of methane, corresponding $384 \mathrm{~m}^{3}(756 \mathrm{~kg}) \mathrm{CO} 2$ equivalent. In palm oil mills new technologies had been developed to overcome these issues [4 -5] but these processes still produce lots of POME but the eco-mill process indeed can eliminate or greatly reduce the amount of POME to the ponds because there is no addition of water required during $\mathrm{CPO}$ separation at megasonic clarification and other processes as well.

The problems and issues of conventional process and advantages of new generation megasonic clarification process is shown in Table.1.

TABLE I: STATE OF THE ART MEGASONIC PROCESS OVER CONVENTIONAL CLARIFICATION PROCESS

Conventional Clarification Process

High water consumption
New Generation Megasonic Clarification Process

A simple and reliable process for the oil clarifying stage in the palm oil mill and eliminating the need for hot water 
Proc. of the Intl. Conf. on Advances in Applied science and Environmental Technology - ASET 2015. Copyright (C) Institute of Research Engineers and Doctors, USA .All rights reserved.

ISBN: 978-1-63248-040-8 doi: 10.15224/ 978-1-63248-040-8-39

\begin{tabular}{|l|l|}
\hline $\begin{array}{l}\text { High energy consumption to maintain the water } \\
\text { temperature and many systems involved in the process }\end{array}$ & $\begin{array}{l}\text { Energy consumption is less. This process will reduce energy which } \\
\text { is currently used by the hot water system and the decanter system }\end{array}$ \\
\hline $\begin{array}{l}\text { Complicated processes leading to big foot-print at the } \\
\text { mill and high maintenance as well as causing noise and } \\
\text { vibration }\end{array}$ & A simple and smaller foot-print system \\
\hline $\begin{array}{l}\text { Production of Palm Oil Mill Effluent (POME) which } \\
\text { requires big tracts of land to build the effluent ponds }\end{array}$ & $\begin{array}{l}\text { This process generate only very less amount of sludge or waste } \\
\text { water known as Palm Oil Mill Effluent (POME) to be discharged } \\
\text { into the effluent ponds }\end{array}$ \\
\hline $\begin{array}{l}\text { Loss of Crude Palm Oil through the discharge of the } \\
\text { POME }\end{array}$ & $\begin{array}{l}\text { This process will generate the optimum oil recovery for the palm oil } \\
\text { mill }\end{array}$ \\
\hline
\end{tabular}

\section{I. a Problems and issues of conventional sterilization process}

The steam consumption was extremely high for conventional sterilization process i.e $140 \mathrm{~kg} / \mathrm{ton}$ FFB for a single-peak cycle to $224 \mathrm{~kg} / \mathrm{ton}$ FFB for a triple - peak cycle [5]. Eco-mill process can greatly reduce the amount of water and energy used to cook the fruitlets.

TABLE II: ULTRASONIC HORN OIL BURSTING PROCESS OVER CONVENTIONAL PROCESS

\begin{tabular}{|l|l|}
\hline Conventional Sterilization process & Ultrasonic horn press process \\
\hline This is a wet process. So, water consumption is high & This is a dry process. So, water consumption is less \\
\hline High energy consumption & $\begin{array}{l}\text { This process will reduce the amount of energy used to cook the fresh } \\
\text { fruit bunches }\end{array}$ \\
\hline $\begin{array}{l}\text { Large amounts of waste water released to POME which } \\
\text { contains solid and liquid materials which causes } \\
\text { pollution problem including green house emission }\end{array}$ & $\begin{array}{l}\text { This process will help to develop an eco friendly process i.e. no } \\
\text { pollution }\end{array}$ \\
\hline Process time is also high & Shorter process time \\
\hline More noise and vibration & Less noise and vibration \\
\hline
\end{tabular}

Overall, eco-mill takes the holistic approach in using the latest technologies such as megasonic clarification and ultrasonic horn press system and best practices to address the issues so as to produce a food-grade mill with small footprint, dry system, less discharge of POME and higher oil recovery rate and with high energy efficiency. By using this new oil recovery technologies an addition of water is

\section{Experiments}

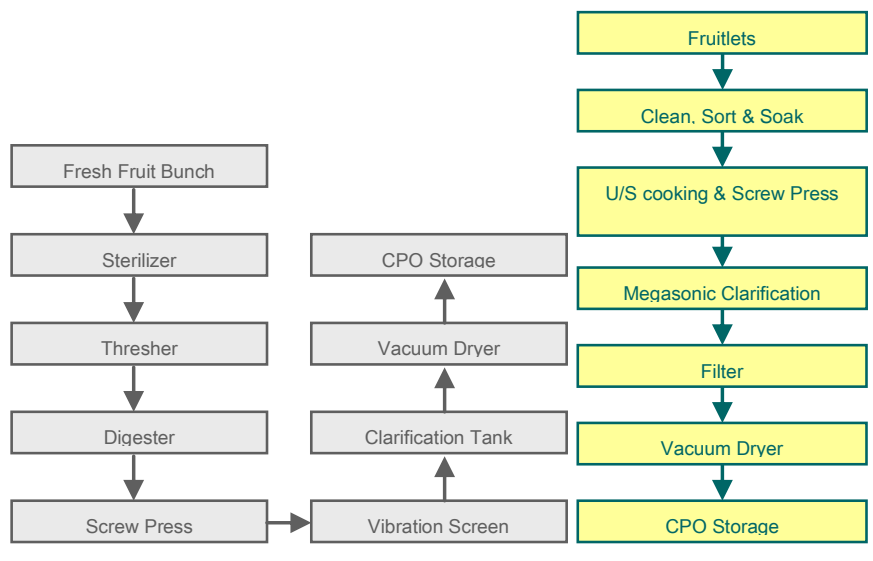

Fig.1Conventional process flow flow not necessary anymore and the amount of effluent can be reduced drastically (almost zero discharge).

In this paper, the megasonic clarification process to replace conventional clarification process, ultrasonic horn press process to replace conventional sterilization process and the effect of temperature on quality of oil was studied.

Conventional palm oil mill process flow and eco-mill process flow used for this study was shown in Fig.1 and Fig.2. In eco-mill process the fruitlets are washed with nozzle type water spray to remove mud, sand etc from the fresh fruitlets. The washed water is passed through the filter and reused again. The fruitlets are categorized using sizing machine or some of the other sorting methods based on the diameter of the fruitlets and then the fruitlets are soaked in the water with temperature around $80{ }^{\circ} \mathbf{C}$ for $20 \mathrm{~min}$ to soften the fruitlets before subjects to ultrasonic horn press. The ultrasonic horn used for this study was as shown in Fig.3. The precooked fruitlets are fed into the ultrasonic horn by using fruit hopper. The Crest ultrasonic horn system rupture the oil cells within the palm fruits and press the oil emulsion out from the fruits at the same time. The virgin oil released during sonic press is collected in the tray and the 
horn pressed fruitlets are sent to the screw press to extract the oil emulsion out from the fruitlets. The extracted oil emulsion is filtered using vibrating screen filter to remove the fibers and sand etc. The filtered oil is heated around 75
${ }^{\circ} \mathbf{C}$ to reduce the viscosity of the oil prior to megasonic clarification process. The megasonic clarification set up used for this study was shown in Fig. 4.

\section{Ultrasonic horn press}

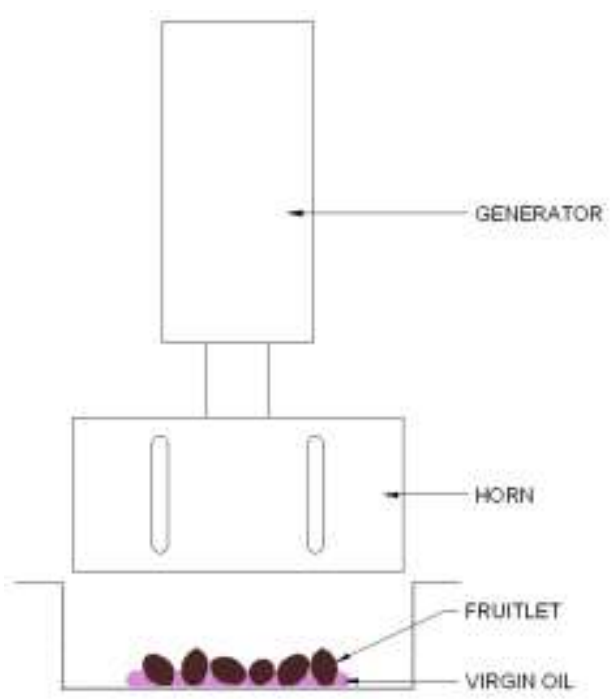

Fig.3 Schematic of U/S horn press

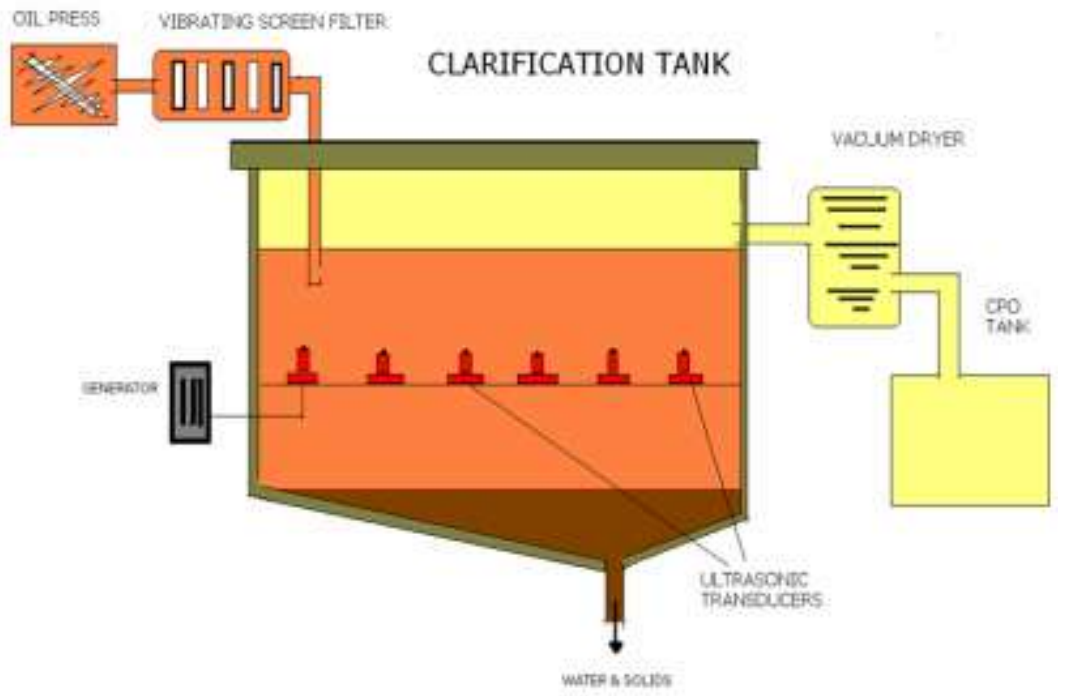

Fig. 4 Schematic of Megasonic oil clarification system
The ultrasonic horn press assembly consists mainly of 4 components i.e. 1. Ultrasonic generator 2. Transducer 3. Booster and 4. Ultrasonic horn/Sonotrode. Ultrasonic generator converts the line voltage to the desired high frequency electrical energy. The frequency and power tested for this study was $25 \mathrm{kHz}, 35 \mathrm{kHz}, 40 \mathrm{kHz}$ and $2000 \mathrm{~W}$ respectively. The high frequency electrical energy produced by the generator is sent to the transducer, which changes the electrical energy to the high frequency mechanical vibrations. These mechanical vibrations are transmitted to a booster, which is used to increase or decrease the amplitude of the vibrations. The amount of amplitude required to rupture the fruitlets mainly depends on the number of fruitlets placed on the tray for pressing and also the condition of the fruitlets. The vibrational energy is then transmitted to a horn with proper size and shape to best deliver the vibrational energy to the fruitlets.

The size of the horn tested for this study was $60 \mathrm{~mm}$ dia, $110 \times 110 \mathrm{~mm}, 170 \times 170 \mathrm{~mm}$ and $190 \times 170 \mathrm{~mm}$. The 60 $\mathrm{mm}$ dia horn can cover only one or two fruitlets per press, 110 x $110 \mathrm{~mm}$ horn size can cover $\sim 12$ fruitlets, $170 \times 170$ $\mathrm{mm}$ horn size can cover $\sim 40$ fruitlets and $190 \times 170 \mathrm{~mm}$ horn size can cover $\sim 50$ fruitlets per press. The amount of energy (watt/unit area) transferred to the fruitlets are good enough to rupture the fruitlets and press the oil emulsions out from the fruitlets until the horn size is $170 \mathrm{x} 170 \mathrm{~mm}$ but for $190 \times 170 \mathrm{~mm}$ horn size the ultrasonic energy is not sufficient enough to rupture all fruitlets at the same time.
In ultrasonic horn pressing process the fruitlets to be cooked or ruptured are placed in the tray as shown in Fig.3. The horn is brought into contact with the upper surface of the fruitlets with specified pressure. The horn vibrates vertically 20,000 times per second - 40,000 times per second for 20$40 \mathrm{kHz}$ frequency. During this vibration the horn transfers the mechanical vibrational energy to the fruitlets to be cooked. The mechanical vibrational energy become heat energy when the horn presses the fruitlets with some applied force or pressure. This action rupture the oil cells within the palm fruits and press the oil emulsion out from the fruitlets at the same time with lower temperature. In addition this system also replaces the traditional sterilizer system. The cooking of palm fruitlets mainly depends on the contact time, amplitude, pressure, frequency and so on. The horn pressed fruitlets are sent to the screw press to squeeze the oil out of a mixture of oil, moisture, fiber and nuts by applying mechanical pressure on the screw pressed and digested mash fruitlets.

\section{Megasonic clarification tank}

The megasonic oil clarification (MOC) system used for this study was shown in Fig. 4. A mixture of oil, water, solids from the fruitlets is delivered from the press to a clarification tank. In the conventional process, separation of the oil from the rest of the liquor is achieved by settling tanks based on gravity. The oil mixture is heated to $90{ }^{\circ} \mathrm{C}$ 
and allowed to separate in the clarification tank. A settling time of 1-3 $\mathrm{hr}$ is used to separate the CPO from its other entrained impurities. Oil from the top is skimmed off and purified in the centrifuge prior to drying in vacuum dryer. In eco-mill process, screw pressed crude oil samples are heated to $70{ }^{\circ} \mathrm{C}$ prior to megasonic clarification process to reduce the viscosity of the oil thereby improve the megasonic activity during clarification process. The megasonic oil clarification system is used to separate the clarified oil from its other entrained impurities. This system can replace the conventional clarification system. The Ultrasonic Palm Oil tank can be integrated into the Ultrasonic Palm oil Processor whereby the oil emulsion is clarified and the clarified oil is separated from other entrained impurities using Crest 360 $\mathrm{kHz}$ ultrasonics.

Ultrasonic waves at the required high frequency will generate millions of microscopic bubbles and acoustic streaming [6] in the palm oil emulsion which helps to separate/extract the oil bearing molecules from the other entrained impurities more effectively and much faster than the conventional clarification process. The separation of the oil and other impurities takes place immediately upon the application of the megasonic sound and the whole process to create a sufficiently clear crude palm oil can takes place between 10 minutes - 15 minutes depending on the ultrasonic frequency, the power applied and the temperature of the palm oil emulsion. The conventional clarification process required addition or dilution of water to separate the CPO but for megasonic clarification process no addition of water or dilution is required. So, the release of POME to the ponds will be reduced significantly. The high acoustic streaming and cavitation implosion generated by the megasonic frequencies and also the heat associated with the sonic can enhance the oil separation process with high yield with high quality. The advantages of MOC system over other conventional process is that the separation occurs within shorter period of time $(10-15 \mathrm{~min})$ as compared to conventional clarification system ( $3 \mathrm{hrs})$. The separation also occurs with lower temperature (around $80{ }^{\circ} \mathrm{C}$ ) as compared to $>90{ }^{\circ} \mathrm{C}$ for conventional clarification system. The separation of oil after megasonic clarification is shown in Fig. 6. From Fig. 6, it can be seen that there is a clear layer of oil formed at the top and other residues formed at the bottom of the beaker within short period of time $\sim 10$ min. The oil rich layer is separated out from the beaker and checked the quality of the oil.

\section{Results and Discussion}

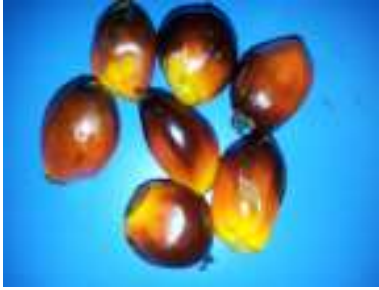

Fig. 5 Fresh Fruitlets

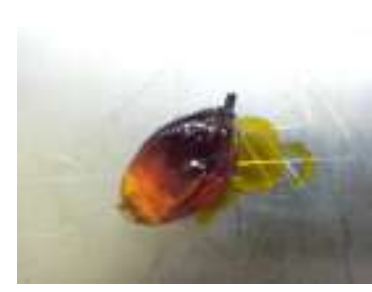

Fig.5a Fruitlets after sonic bursting

Fig.5a clearly indicates that the ultrasonic horn system ruptured the oil cells within the palm fruits and also presses the oil emulsion out from the fruitlets at the same time. From Fig. 6, it can be observed that there is some virgin oil comes out from the fruitlets for each press. The nutrition fact in virgin oil is extremely good as compared to RBD oil (Refined, Bleached, and Deodorized). The Virgin Palm Oil is palm oil that is traditionally made and maintains the natural nutrients of carotenes (precursors to Vitamin A) and the antioxidant tocotrienols (Vitamin E). Typical RBD palm oil has these nutrients stripped from them resulting in clear oil. In its natural state, palm oil is red in color due to a high concentration of carotenes and tocols. Oils and fats generally are susceptible to attack by atmospheric oxygen, resulting in rancidity. Virgin Palm Oil contains tocols (Vitamin E) which are powerful natural antioxidants. Therefore, it has exceptional resistance to rancidity. Virgin

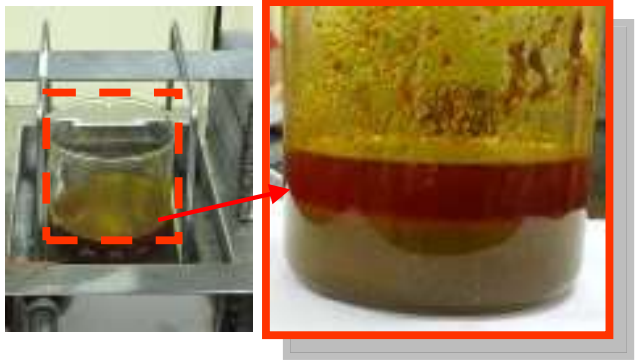

Fig. 6 Separation of oil after megasonic process

Palm Oil is known for its excellent stability at high temperatures. So, the demand for virgin oil has been high in future.

Fig. 6 shows the formation of oil after subjects to megasonic separation process. The result indicates that there is a clear two distinct layer formed after megasonic clarification process. The oil is formed at the top and other residues formed at the bottom. The clarified oil is separated out and sent for lab analysis to find the quality of oil. The analysis summary obtained for megasonically clarified oil is shown in Table.3. From Table 3, it can be seen that the DOBI value is significantly higher for eco-mill process as compared to conventional process (DOBI value: 3.2). Higher DOBI values achieved for eco-mill process will reduce the cost associated with further refining process. The experiments also carried out with various temperatures of megasonic 
Proc. of the Intl. Conf. on Advances in Applied science and Environmental Technology - ASET 2015. Copyright (C) Institute of Research Engineers and Doctors, USA .All rights reserved.

ISBN: 978-1-63248-040-8 doi: 10.15224/ 978-1-63248-040-8-39

clarification process. From Table 4, it can be seen that the

TABLE III: PARAMETERS MEASURED TO CHECK THE QUALITY OF OIL

\begin{tabular}{|l|l|l|l|l|l|l|}
\hline & FFA & DOBI & MOISTURE & DIRT & M \& I & $\begin{array}{l}\text { IODINE } \\
\text { VALUE }\end{array}$ \\
\hline CPO & 2.8029 & 4.54 & 0.3195 & 0.0580 & 0.3775 & 51.90 \\
\hline & 2.8052 & 4.55 & 0.3148 & 0.0604 & 0.3752 & 52.00 \\
\hline Avg & 2.804 & 4.55 & 0.0317 & 0.0592 & 0.3764 & 51.95 \\
\hline
\end{tabular}

\section{Overall design proposal:}

The overall fully automated eco-mill system was proposed to cater for 1 ton mill. The sizes of the megasonic clarification tank, number of clarification tanks and number of horns to cater for 1 ton mill was also addressed in this design. The proposed process can separate the CPO effectively from its other entrained impurities, enhance the oil yield and minimize or eliminate the POME discharge into the pond. The treatment of POME using ultrasonics and bio-reactor is also studied. The preliminary results shows that the treatment of POME using ultrasonics indicates that

\section{Conclusion}

Eco-mill process was demonstrated successfully in laboratory scale level to overcome the current palm oil mill issues such as vast Palm Oil Mill Effluent ponds, large mill area, reliance on water supply, oil quality, oil loss, and more energy etc. Megasonic clarification process was developed for effective separation of CPO from its other entrained impurities with lower temperature around $80{ }^{\circ} \mathrm{C}$ and also with shorter period of time $\sim 10 \mathrm{~min}$. The oil loss and POME waste will be greatly reduced due to effective separation of oil and also there is no addition of water or dilution involves in the megasonic clarification process and other process as well. Megasonic frequency also helps to breakdown the larger oil bearing molecules to smaller

\section{Acknowledgment}

We wish to thank Tjung (Managing Director), Beng Hooi (Manager Sales Dept), and Research and Development team (ACT, Penang) for their kind support for this project.

\section{References}

[1] Chungsiriporn, J, Prasertsan, S and Bunyakan C, "Minimization of water consumption and process optimization of palm oil mills", Clean Technologies and Environmental Policy, Vol. 8(3), pp. 151-158, 57, 2006.

[2] Schuchardt F, Susilawati E, and Guritno P, "Influence of $\mathrm{C} / \mathrm{N}$ ratio and inoculums upon rotting characteristics of oil palm empty fruit bunch.", Anon. Proceedings of International Palm Oil Conference Bali, Indonesia, September 23-25, pp 501-510, 1998.

[3] Schuchardt F, Susilawati E and Guritno. P, "Trials about composting of solid wastes from palm oil mills in Indonesia", Anon. Biological
DOBI value decreases with increase of temperature.
TABLE IV: EFFECT OF TEMPERATURE ON OIL QUALITY

\begin{tabular}{|l|l|l|l|l|l|l|}
\hline NO & $\begin{array}{l}\text { Temp } \\
\text { C }\end{array}$ & DOBI & FFA & DIRT & $\begin{array}{l}\text { M } \\
\text { \& I }\end{array}$ & $\begin{array}{l}\text { IODINE } \\
\text { VALUE }\end{array}$ \\
\hline 1 & $\begin{array}{l}75- \\
80\end{array}$ & 3.75 & 2.32 & 0.0580 & 0.37 & 51.90 \\
\hline 2 & $85-90$ & 3.46 & 2.35 & 0.0604 & 0.39 & 51.80 \\
\hline
\end{tabular}

ultrasonics can helps to separate the oil effectively from POME prior to conventional treatment process. Introducing ultrasonic process prior to conventional treatment process can improve the treatment time, oil yield, reduce COD, $\mathrm{BOD}$, etc. In case of bio-reactor the bacteria used to digest the POME can not grow if the oil in the POME exceeds certain level. So, ultrasonic treatment is essential to remove the oil from POME prior to bio-reactor treatment process. Low ultrasonic high intensity frequency such as $40 \mathrm{kHz}$ and $58 \mathrm{kHz}$ would be the better choice for POME treatment.

molecules and therefore helps to reduce BOD and COD. The environmental problem associated with palm oil mill process is also reduced. Crest ultrasonic horn system was developed to rupture the oil cells within the palm fruits and also press the oil emulsion out from the fruitlets within 20 sec. This system indeed can replace the conventional sterilization system. This process also reduces the energy associated with sterilization process. The result shows that DOBI value is significantly higher $(>4)$ for eco-mill process as compared to conventional process (DOBI value: $\sim 3.2$ ). Higher DOBI values achieved for eco-mill process will reduce the cost associated with further refining process.

Treatment of Waste and the Environment. Intern. Conference, ORBIT 99, September 2-4, Weimar, Germany, pp 155-164, 1999.

[4] Schuchardt F, Darnoko D, and Guritno P, "Composting of empty oil palm fruit bunch (EFB) with simultaneous evaporation of oil mill waste water (POME)", IOPRI (ed). Enhancing oil palm industry development through environmentally friendly technology, Proceedings of Chemistry \& Technology Conference, Nusa Dua Bali, Indonesian, July 8-12, pp 235-243, 2002a.

[5] Schuchardt F, Wulfert K, and Darnoko D, "A new, integrated concept for combined waste (EFB) and waste water (POME) treatment in palm oil mills - Technical, economical and ecological aspects", Anon. Enhancing oil palm industry development through environmentally friendly technology, Proceedings of Chemistry \& Technology Conference, Nusa Dua Bali, Indonesian, July 8-12, pp 330-343, 2002b.

[6] Vetrimurugan et al., "Experimental Investigation of Ultrasonic and Megasonic Frequency on Cleaning of Various Disk Drive Components", International Journal of Chemical Engineering and Applications", Vol.4, No.4, pp. 174-177, 2013. 